\title{
Agroindustrial Study of Banana Crackers and Salai Based on Income, Value Added and Break Even Point
}

\section{Lukman Hidayat*, Hidayat Koto, and Odi Andanu}

\author{
Department of Agricultural Technology, Faculty of Agriculture, University of Bengkulu \\ *Email address: lukman_hidayat@unib.ac.id
}

\begin{abstract}
The aim of this research was to calculate and analyse the income, added-value, and break even point of agroindustry that processing bananas into banana crackers and salai. Data were collected using observation and interview. Data were analysed using descriptive analysis, qualitative and quantitative, for the value-added, income, Break Even Point (BEP) and Revenue Cost ratio $(\mathrm{R} / \mathrm{C})$. The results shown that the average of value added per kilograms for Salai Rp. 4,371.37, sweet and salted banana crackers are $\mathrm{Rp} 2,944.00$ and $\mathrm{Rp} 3,627.90$. The income of salai, sweet and salted banana crackers per year are Rp. 29,566,251.00, Rp. 18,437,067.96 and Rp. $20,286,567.00$ respectively. On average of BEP per month's for salai is Rp. 1,415,636,-, sweet and salted banana crackers are Rp. 988,966,- and Rp.781,352.- or 145 packs per month, 124 packs and 98 packs respectively. In term of $\mathrm{R} / \mathrm{C}$, it is found that $\mathrm{R} / \mathrm{C}$ ratio are $1.66,1.49$ and 1.71 respectiveley for salai, sweet and salted banana. On average of income, banana salai give value added higher than salted banana followed by sweet crackers.
\end{abstract}

Key words: Value Added, Income, Banana crackers, Salai, Break Even Point

Citation to this paper should be made as follows :

Hidayat, L., H. Koto, and O. Andanu. 2018. Agroindustrial Study of Banana Crackers and Salai Based on Income, Value Added and Break Even Point. Agritropica: Journal of Agricultural Science. 1 (1): $37-46$. DOI: https://doi.org/10.31186/J.Agritropica.1.1.37-46

\section{INTRODUCTION}

Agricultural commodities are generally produced as raw materials and easily damaged, so they need to be consumed or processed. One of the comodities that is able to support the establishment of several industries is a banana. Banana has a wide use because in addition to raw materials for food and non-food industries as well as household consumption (Simin, 2014). Banana can be processed into banana chips, flour, cassava, banana salai, dodol, juice, and jam. Agroindustry is basically an agriculture based industry to value added from agricultural commodities and improve agricultural products (Pratiwi, 2015). Agricultural product processing industry is divided into several types, namely large and medium industries, small industries and home industries.

Tebat Monok Village, Kepahiang Subdistrict, Kepahiang Regency is a village where there are many home industries that process banana into banana chips and banana salai. Untill now, the number od industries that process bananas has reached 10 home industries, thus making the village of Tebat Monok as a souvenir center for tourist from within and outside of Kepahiang City. The factors that encourage people in Tebat Monok to process banana into banana crackers and banana salai among others, because of the availability of banana raw materials are many, the desire to increase income, the location of a strategic village road crossing KepahiangBengkulu and this industry can creat a field 
work. Kepahiang regency is one of the regencies having the highest production of banana in Bengkulu Province which is 32,955 quintal or 3,295.5 ton (BPS of Kepahiang Regency, 2016). One of the agroindustry that process banana into banana crackers and banana salai is WAHYU home industry that has been establish since 2009. Now has 7 employees who help the production process. The main raw materials of banana comes from the farmers of Kepahiang Regency and Rejang Lebong Regency. As a health and food security guarator produced by WAHYU's home industry has obtained permission from Public Health Office for banana processing product Number: P-IRT. No. 21571708000-21 whereas processing of sweet potato Number: P-IRT. No. 21417080008-21.

Development of agro-industry of banana crackers and banana salai in Tebat Monok Village, Kepahiang Subdistrict, Kepahiang Regency is still faced with several obstacles such as high production costs and the production of raw materials processed fluctuative. The process of food industry is an instrument of income and value added for agricultural commodities. Adding value to agricultural products beyond the farm gate usually has several times the economic impact of the agricultural production alone. In addition to increasing the added value of a raw product, the processing is also aimed at overcoming one of the weaknesses of agricultural products, including bananas, which are easily decayed or pershable. Many research also concluded that further processing of raw agricultural products are feasible in finnacial aspects. Among others are research by Reswita (2014), and Nasaruddin et al (2015). Further more, the purpose of processing is to generate income, with the income of the future operations of the company will run well or in the other words that income is a tool for the survival ot the company (Rahman, 2015). Revenue in question is all goods and services and money received both individually and community groups within a certain period.

One of the factors that support high or low income is the value added of the product. Economic value added (EVA) is an indicator which is widely used as the main tool for financial analysis (Zdeñk, 2011). Imran (2014) suggests that value added is the addition of the value of a product before the production process was done after the production process. Meanwhile, according to Sudiyono (2004) value added can be seen from two sides: value added fpr processing and added value for marketing. Value added for processing is influenced by technicl factors: production capacity, raw materials quantity, and labor, as well as market factors including output prices, auxiliary materials and fuel.

Based on above discussion, this paper is aimed at examining and analysing financial performance or financial feasibility of banana salai, sweet and salted banana crackers in WAHYU home industry. The feasibility indicators used in this research includes income, value added, break even point, and $\mathrm{R} / \mathrm{C}$ ratio.

\section{RESEARCH METHODOLOGY}

This research has been conducted in WAHYU's home industry Tebat Monok Village Kepahiang Subdistrict Kepahiang Regency on November 2017. Secondary data obtained from the data archived each month during the last year of December 2016 until November 2017, as for the research materials are:

\section{Fixed Cost}

Fixed costs are those costs that are always fixed or fixed or fixed trends for a period and are not affected by the amount of production (Irmayani, 2015). Fixed costs consist of: (a) Salary of permanent employees; (b) Depreciation of tools and buildings / warehouses; and (c) Payment of taxes 


\section{Variable Cost}

Variable costs are costs that are always changing in accordance with the amount of production (Irmayani, 2015). Variable costs consist of (a) The main raw material of bananas, (b) Auxiliary raw materials, (c) Employee salary is not fixed; and (d) Fuel and electrical energy

\section{Data analysis}

Data analysis method used in this research is descriptive analysis and quantitative analysis. According to Wiyono (2015) descriptive analysis is used to know the general description and explain about the cost and income of the industrial effort. Quantitative analysis used is the analysis of income and value-added analysis.

\section{Income}

Calculating the business income of banana processing into banana crackers and banana salai using the following formula suggested by Soekartawi (2002) and Purwitari (2016).

a. To calculate income using the following formula:

$\pi=T R-T C$

Note: $\pi=$ income (Rp/month), $\mathrm{TR}=$ Total revenue $(\mathrm{Rp} / \mathrm{month}), \mathrm{TC}=$ Total cost (Rp/month)

b. To calculate the revenue can be calculated using the following formula:

$\mathrm{TR}=\mathrm{Q} \times \mathrm{P}$

Note: $\mathrm{TR}=$ Total revenue $(\mathrm{Rp} / \mathrm{month}), \mathrm{Q}=$ Number of products (Wrap/month), $\mathrm{P}=$ Product price (Rp/package)

c. For the total cost can be calculated by using the following formula:

$$
\mathrm{TC}=\mathrm{TFC}+\mathrm{TVC}
$$

Note: $\mathrm{TC}=$ Total cost $(\mathrm{Rp} /$ month $), \mathrm{TFC}=$ Total fixed cost $(\mathrm{Rp} / \mathrm{month}), \mathrm{TVC}=$ Total variable cost (Rp/month)

\section{Value Added}

Value added means adding value to a raw product by taking it to at least the next stage of production. In this research, value added can be gained by further banana processing into banana salai and banana crackers. It is calculated using the following formula suggested by Purwitari (2016).

a. Gross value added:

$$
\begin{aligned}
\mathrm{NTb} & =\mathrm{Na}-\mathrm{BA} \\
& =\mathrm{Na}-(\mathrm{Bb}+\mathrm{Bp})
\end{aligned}
$$

Note: $\mathrm{NTb}=$ Gross value added $(\mathrm{Rp}), \mathrm{Na}=$ Value of final product $(\mathrm{Rp}), \mathrm{BA}=$ Auxiliary cost $(R p), B b=$ Raw material cost $(R p), B p=$ Cost of helper materials $(\mathrm{Rp})$

b. Net added value:

$\mathrm{NTn}=\mathrm{NTb}-\mathrm{NP}$

$$
N P=\frac{(\text { initial value }- \text { residual value })}{(\text { economic life })}
$$

Note: $\mathrm{NTn}=$ Net added value $(\mathrm{Rp}), \mathrm{NTb}=$ Gross added value (Rp), NP = Depreciation (Rp)

c. Value added raw materials

$\mathrm{NTbb}=\mathrm{NTb}: \Sigma \mathrm{bb}$

Note: $\mathrm{NTbb}=$ Value added raw material used $(\mathrm{Rp} / \mathrm{kg}), \Sigma \mathrm{bb}=$ Number of raw materials used $(\mathrm{Kg})$

Break Even Point (BEP)

Break Even Point Analysis (BEP) is a way to know the minimum sales volume so that the company does not suffer loss before taking profit. The total cost of operations is equal to the total revenue earnd this point (Ndaliman and Suleiman, 2011). Mathematically, it can be expressed as follows (Irmayani, 2015)

a. Break Even Point Unit:

$$
\text { BEP Unit }=\frac{B T}{(h-h v)}
$$

b. Break Even Point Rupiah:

$$
\text { BEP Rupiah }=\frac{B T}{(1-B V / S)}
$$


Note: $\mathrm{BT}=$ Fixed cost $(\mathrm{Rp}), \mathrm{H}=$ Selling price perunit $(\mathrm{Rp}), \mathrm{BV}=$ Variable cost $(\mathrm{Rp}), \mathrm{Hv}=$ variable cost per unit (Rp), $S=$ Total sales $(R p)$

\section{Return Cost Ratio (R/C Ratio)}

Business efficiency is demonstrated by the amount of revenue and costs incurred called Revenue Cost (R/C) ratio. According Soekartawi (2002) business efficiency can be analysed by comparing the revenue with the cost incurred. Thus, business efficiency can be formulated:

$$
R / C \text { ratio }=\frac{\text { Revenue }}{\text { Total Cost }(\text { Fixed }+ \text { Variable Cost })}
$$

The higher $\mathrm{R} / \mathrm{C}$ ratio means the business is more efficient. If $\mathrm{R} / \mathrm{C}>1$ then the business is profitable / efficient, $\mathrm{R} / \mathrm{C}<1$ means the business is experiencing a loss / inefficient, and $\mathrm{R} / \mathrm{C}=1$ then the business is break even.

\section{RESULT AND DISCUSSION}

\section{Production Cost Structure}

Production costs are the sum of Fixed and variable costs in which fixed costs in the home industry of revelation include the costs of electrical loads, water costs of PDAMs and depreciation of equipment. While variable costs include the cost of raw materials (banana ambon, banana scarf and banana horn), auxiliary materials (sugar, salt, rice flour, wheat, vanilla, onion cooking oil and garlic) and other costs (employee salaries, , paper, firewood, electricity, LPG gas, electricity and water utility costs PDAM.

\section{Fixed Cost}

Fixed costs are fixed total costs, not influenced by the size of production or output produced, although the production volume changes (Henry, 2009). Fixed costs represent costs incurred for the payment of fixed inputs in short-term production processes. The use of fixed input does not depend on the quantity of output produced. Fixed costs are divided into three types: load costs such as electricity and PDAM water, business and building tax insurance costs such as SPPT and PBB taxes and equipment depreciation costs.

The fixed costs incurred by the Home Industry Revelation to process sweet and salty banana crackers is Rp. 645,074, -/year. The highest fixed cost is the cost of depreciation of the tool is Rp. 508,151,-/year is the lowest fixed cost is the cost of business and building tax insurance that is Rp. 44,615,-/ year. The fixed costs incurred by the home of revelation to cultivate sweet and salty banana crackers are small. This is because in the home industry revelation produces 13 types of products which in the production process using the same tool. Then the fixed cost for the processing of each product is divided based on the proportion of the use of tools. Capital resources in the processing using their own expenses and not lend in the bank, so that interest capital does not exist.

The fixed costs incurred by the Home Industry Revelation to process banana salai is Rp.575,447.00/ year. The highest fixed cost is the cost of depreciation of the tool is Rp.506,987.00/year is the lowest fixed cost is the cost of business and building tax insurance that is Rp. 22,307.00/ year. The fixed costs incurred by the revelation households to process banana salai are still relatively small, this is because in the household industry revelation produces 13 types of products which in the production process using the same tool. Then the fixed cost for the processing of each product is divided based on the proportion of use of the tool.

\section{Variable Cost}

Variable costs represent costs incurred for the size of the business that is affected by the number of products (output) produced (Henry, 2009). Variable costs are the costs incurred for the payment of variable inputs in the production process. The use of variable input depends on the quantity of output 
produced the greater the quantity of production in general the greater the variable costs used. Variable costs on Wahyu domestic industry on processing banana crackers and salai consists of: banana raw material costs, the cost of auxiliary materials, labor costs, packaging costs and fuel costs. Variable costs incurred for the production of salted banana crackers Rp. 35,520,900.00/ year. The largest variable cost is seen in the cost of auxiliary materials of Rp. 13,590,500.00/ year or about $38 \%$. This shows that the cost of auxiliary materials greatly affects the total variable cost because the cost of the auxiliary material has the greatest amount compared to the other costs. The smallest variable cost seen in the cost of banana raw material is Rp. 10,554,000.00/year.

Variable costs incurred for the production of sweet banana crackers amounted to Rp. $37,374,000.00 /$ year. The largest variable cost is seen in the auxiliary material cost of $14,991,000.00$ /year or about $40 \%$ of the total variable cost. This shows that the cost of auxiliary materials greatly affects the total variable cost because the cost of the auxiliary materials has the greatest amount compared to the other costs. The smallest variable cost is seen in other costs of Rp. 10,987,900.00/year.

Variable costs incurred for the production of salai of Rp. 43,958,300.00/year. The largest variable cost is seen in the cost of raw materials of bananas, namely $17,825,500.00$ /year or about $40 \%$ of the total variable cost. This shows that the cost of banana raw material is very influential on the total variable costs because the cost of banana raw materials has the largest amount compared to other costs. The smallest variable cost is seen in other costs of Rp. 12,714,800.00/year.

\section{Income and BEP}

This section describes the income and BEP of salai, sweet and salted banana crackers.

\section{Salai}

The income of the Wahyu's household industry from banana processing to banana salai for the period of December 2016 November 2017 can be seen as follows:

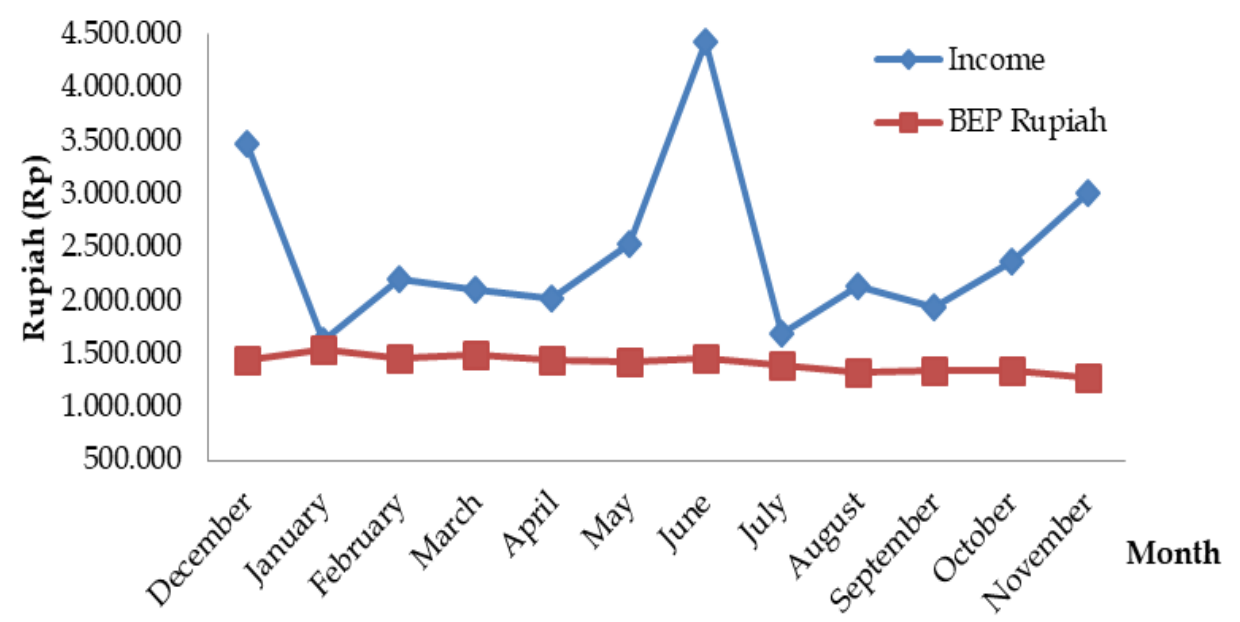

Figure 1 The income and BEP graph of salai (Rp/month)

Based on the graph in Figure. 1, the total amount of salai income earned during the period of December 2016 until November 2017 was Rp. 29,566,251.00/year respectively. The highest salai income occurred in June 2017 Rp. 4,437,384.00 / month and December 2016 Rp.

3.470.884.00/month. The lowest income of salai occurred in January 2017 of Rp. $1,632,284.00 /$ month and July 2017 of Rp. 1,690,112.00/month. In June 2017 and December 2016 was higher than in other months due in June 2017 there was an iedul fitri 
holiday and December 2016 new year holiday. On these day, many local tourists were on vacation and bought souvenirs, resulting in increasing the production for other months. On the other hand, increasing production in sales in the previous month ultimately implied next month production decreased. The monthly income of banana salai is above the Break Event Point (BEP) or breakeven point where the average BEP value per month is Rp. $1,415,636.00 /$ month, therefore the salai processing business is profitable.

\section{Sweet Banana Crackers}

The income of Wahyu's household industry of processing bananas into banana salai or crackers for the period December 2016 November 2017 is presented in Figure 2. Based on this figure, total income earned during the period of December 2016 until November 2017 processing of sweet banana crackers was Rp. $18,437,068.00 /$ year. The highest income of banana crackers was in June 2017 of Rp. $2,871,760.00 /$ month and month of December 2016 of Rp. 2,397,760.00/month. The lowest income of sweet banana crackers occurred in January 2017 of Rp. 881,160.00/month. This is because there was an increased production in the previous month. In March, February and April 2016, the value of income below the Break Event Point (BEP) where the average value of BEP per month is Rp. 988,399.00/month. This is due to low production quantities and fixed costs incurred tend not to change, thus causing the value of income to be small.

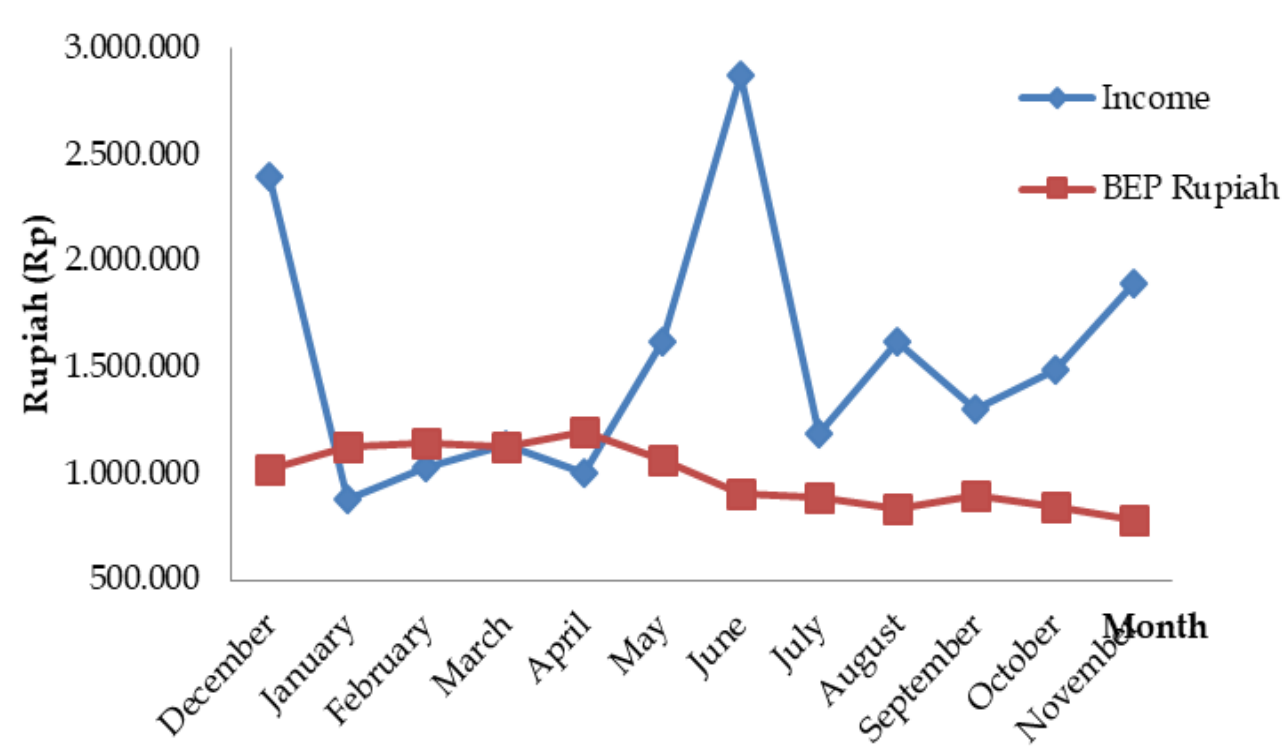

Figure 2 The income and BEP graph of sweet banana crackers (Rp/month)

\section{Salted Banana Crackers}

The income of Wahyu's household industry on processing banana to banana crackers salted for the period of December 2016 - November 2017 can be seen as in Figure 3. By examining Figure. 3, the total income of salted banana crackers was Rp. 20,286,568.00/year. The highest salted banana crackers income occurred in June 2017 and December 2016. The main reason is that June 2017 was Iedul Fitri holiday and December 2016 was a new year holiday. The highest income of salted banana crackers occurred in those months were $\mathrm{Rp}$. $3,607,760.00 /$ month and Rp. $3,338,260.00 /$ month respectively. The lowest Salted banana crackers income occurred in February 2017, amounted to Rp. $839,360.00 /$ month. The monthly income of salted banana crackers processing is above BEP where the average BEP value is $R p$. 
$781,352.00 /$ month, so that the business of salted banana crackers processing is profitable.

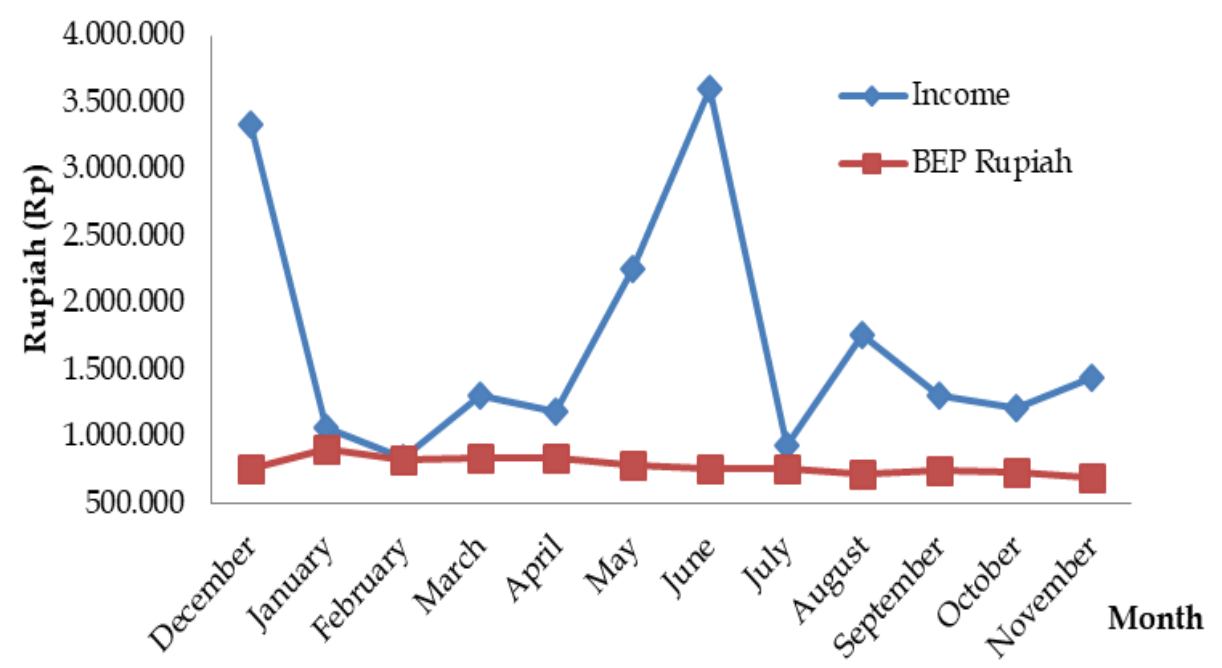

Figure 3 The income and BEP of salted banana crackers (Rp/month)

\section{Value Added}

The value added is the addition of the value of a product before the production process is done after the production process (Imran, 2014). The value added is given by agroindustry in addition to maintain and increase the quality of agricultural products which in turn it can also increase its economic value by processing raw products into a processed product. Figure 4 presents the added value of three commodities being reseached from December 2016 to November 2017.

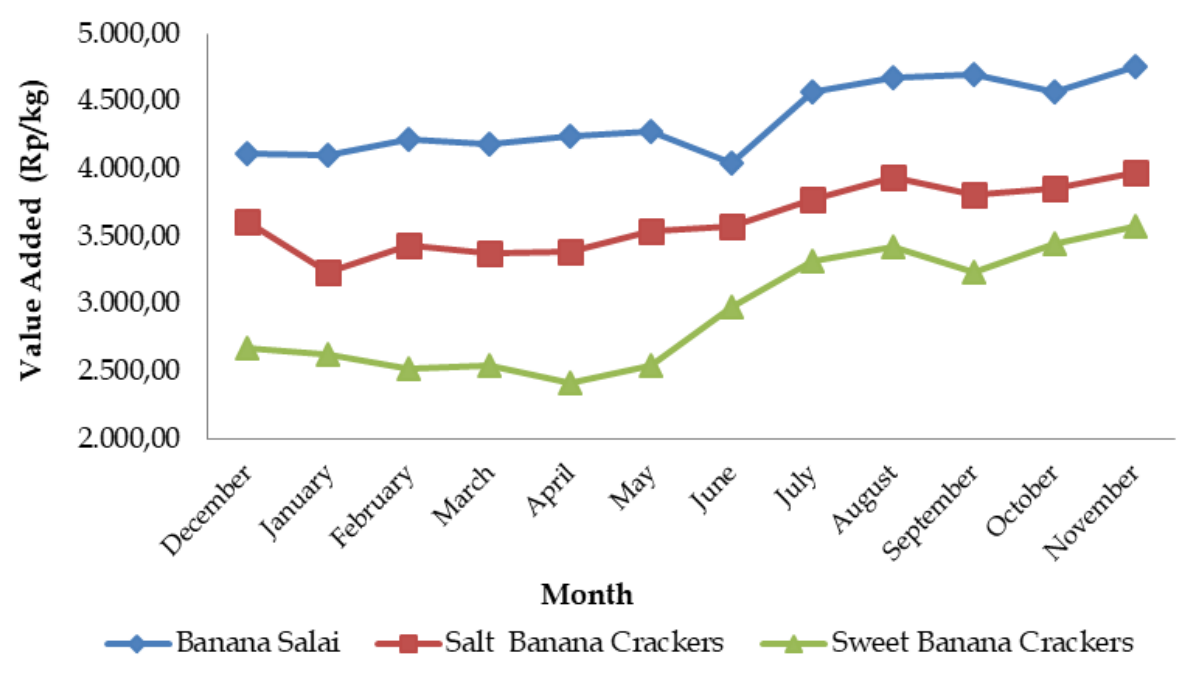

Figure 4 The Value Added graph of Salai, Sweet and Salted Banana Crackers (Rp/month)

Based on Figure 4, the value-added of processing banana salai, salt banana crackers, and sweet banana crackers varies. The highest added value of banana processing products is banana salai products with an average of $\mathrm{Rp}$. $4,371.37 / \mathrm{kg}$, followed by salted banana crackers Rp. 3,627.90/kg and sweet banana crackers Rp. 2,944.00/kg. The differences of banana salai, sweet banana crackers and salted banana crackers added value are due to the price of banana raw material, variable cost 
types, product selling prices and depreciation cost of the utensils.

The highest value added salai occurred in November 2017 which is worth of Rp. $4,761.37 / \mathrm{kg}$ and the lowest in June 2017 worth of Rp. 4,048.38/ kg. The highest value added sweet banana crackers occurred in November 2017, i.e., worth of Rp. 3,580.78/ $\mathrm{kg}$ and the lowest was in April 2017, worth of Rp. $2,418.59 / \mathrm{kg}$. The highest banana crackers value added was in November 2017 worth of Rp. $3,976.92 / \mathrm{kg}$ and the lowest in January 2017, worth of Rp. 3,232.39/kg. These difereences were caused by the fluctuation monthly productions and variable costs used in the production process. Other factors were equipment depreciation costs. According Purwitasari (2016), one of the factors that influence the value added is depreciation expense including the cost of replacement for damage and maintenance.

In the period of December 2016 to June 2017, the process of frying banana salai, sweet banana crackers and salted banana crackers still used LPG gas, after that period July 2017 until November 2017 frying process used firewood resulting in decreasing variable costs. Banana salai period Desember 2016 - June 2017 value added was averagely Rp. 4,168.63/kg, while in the period of July 2017 - November 2017, it was Rp. $4,655.20 / \mathrm{kg}$. This means that there is an increase of Rp. $486.58 / \mathrm{kg}$ in value added. For sweet banana crackers, the value added was Rp. 2,615.93/ kg averagely for the period December 2016 - June 2017 while in the period of July 2017 - November 2017, it worths Rp. $3,403.30 / \mathrm{kg}$ or an increase of Rp. $787.37 / \mathrm{kg}$. Furthermore, averaged value added of salted banana crackers was Rp. 3,452.86/ kg and Rp. $3,872.97 / \mathrm{kg}$ for the period of December 2016 June 2017 and the period of July 2017 November 2017 respectively.

\section{Return Cost Ratio (R/C)}

Analysis of Return Cost Ratio (R/C) is the comparison between revenue (Return $=R$ ) with total cost $($ Cost $=C)$ (Soekartawi, 2002). Looking at the $\mathrm{R} / \mathrm{C}$ value, it can be decided whether a business is profitable or not. It is reasonable that a business will benefit if the revenue is greater than the total cost. Estmation of $\mathrm{R} / \mathrm{C}$ Ratio on banana processing in Wahyu Household Industry can be seen as follows:

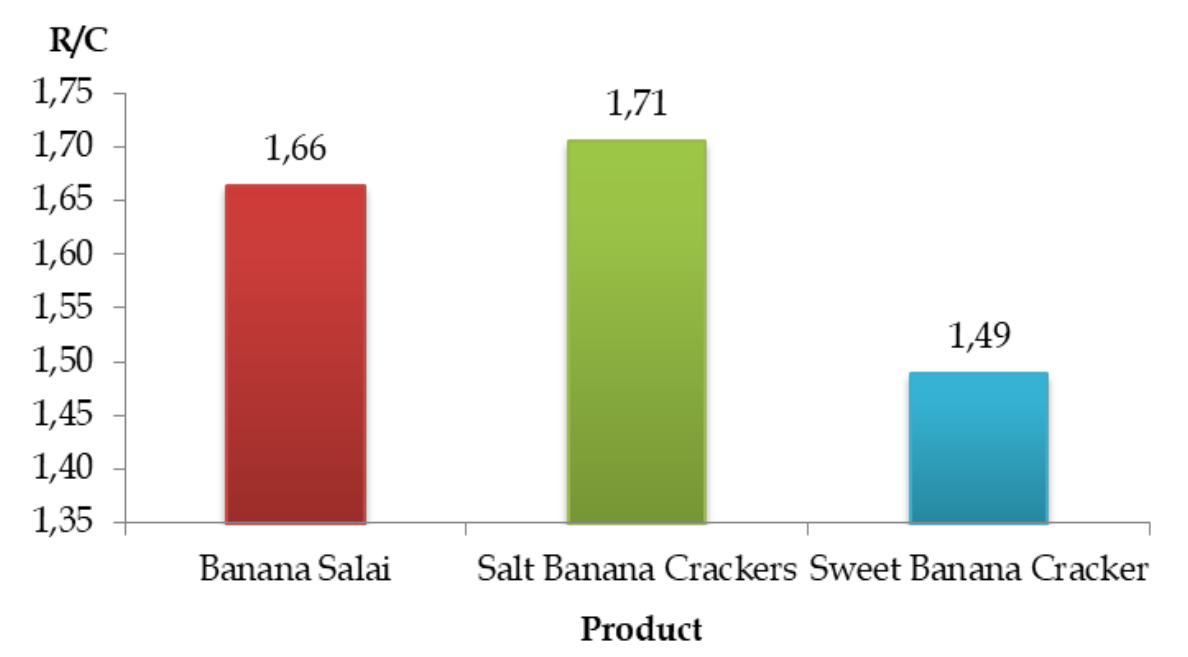

Figure 5 The R/C chart of salai, sweet and salted banana crackers

From the chart above, the the highest value of $\mathrm{R} / \mathrm{C}$ is salted banana crackers, i.e., approximately 1.71 , followed by salai product and sweet banana crackers with the value of 1.66 and 1.49 respectively. All these values indicated that the business is efficient and profitable because their $\mathrm{R} / \mathrm{C}$ values are hinger than 1 . For this reason, it can be concluded that the Wahyu's Household Industry in processing bananas into banana crackers and salai is 
profitable. The highest $\mathrm{R} / \mathrm{C}$ value occurs in salted banana crackers products because salted banana products have a cost of Rp. $35,843,432.00 /$ year and revenue of $\mathrm{Rp}$. $61,130,000,-/ y e a r$. The lowest $\mathrm{R} / \mathrm{C}$ value of sweet banana crackers has a cost of Rp. $37,692,932.00 /$ year and revenue of $\mathrm{Rp}$. 56,130,000.00/year.

\section{Differences in Income and Value Added}

Differences in the value of income and value added processing of bananas into banana crackers salty, sweet banana crackers and banana salai in Wahyu's home industry period December 2016 - November 2017 can be seen in

Table 1.

Table 1 Differences in the Value of Income, Value Added, BEP and R/C of Salai, Salted and Banana Crackers.

\begin{tabular}{lrrr}
\hline \multicolumn{1}{c}{ Observe } & \multicolumn{1}{c}{ Salai } & $\begin{array}{c}\text { Salted Banana } \\
\text { Crackers }\end{array}$ & $\begin{array}{c}\text { Sweet Banana } \\
\text { Crackers }\end{array}$ \\
\hline Value added(Rp/kg) & $4,371.37$ & $3,627.90$ & $2,944.00$ \\
Income (Rp/year) & $29,566,251.00$ & $20,286,567.00$ & $18,437,067.96$ \\
BEP Unit (pcs/mont) & 145.00 & 98.00 & 124.00 \\
BEP Rupiah (Rp/month) & $1,415,636.00$ & $781,352.00$ & $988,966.00$ \\
R/C Ratio & 1.66 & 1.71 & 1.49 \\
\hline
\end{tabular}

Based on Table 1, the highest valueadded is banana salai products of $\mathrm{Rp}$. $4,371.37 / \mathrm{kg}$ while the lowest added value is sweet banana crackers Rp. 2,944.00,-/ kg. The difference of value added between salai and salted banana crackers were Rp. 743.47/ kg, and than with sweet banana crackers were Rp. $1,427.37 / \mathrm{kg}$

Total income from processing banana to banana crackers and salai of Rp. $68,289,886.00 /$ year. The highest icome on banana processing salai of Rp. $29,566,251.00 /$ year. It is followed by sweet banana crackers and banana crackers with the value of Rp. 18,437,067.96/year and Rp. $20,286,567.00 /$ year respectively. The income difference beetwen salai income with salted banana crackers is Rp. 9,279,684.00/year, banana salai with salted banana crackers $\mathrm{Rp}$. 11,129,183.00/year.

In term of BEP in unit, the amount of production to break even for banana salai is 145 packs. With this amount of production, producers will not experience the loss or profit. That is, the amount of revenue is equal to the amount of cost that is sacrificed. For sweet and salted banana crackers, the break even production is 124 packs and 98 packs respectively. In term of rupiah, the value of productions is Rp. $1,415,636.00$, Rp. $988,966.00$ and Rp. 781,352.00 respectively for banana salai, sweet and salted banana crackers correspondingly.

Looking at the $\mathrm{R} / \mathrm{C}$ ratio as presented in Table 1, it can be concluded that salted banana crackers is the most efficient products to manufacture. This conclusion is based on the highest R/C Ratio owned by salted banana, i.e., 1.71. It is followed Salai and sweet banana respectively with the $\mathrm{R} / \mathrm{C}$ ratio of 1.66 and 1.49 .

\section{CONCLUSION AND RECOMENDATION}

The average banana salai added value was Rp. 4,371.37/kg, salted banana crackers Rp. 3,627.90/kg and sweet banana crackers Rp. $2,944.00 / \mathrm{kg}$. The difference of added value for banana salai was bigger than Rp. $743.47 / \mathrm{kg}$ compared to salted banana crackers, for $1,427.37 / \mathrm{kg}$ compared to sweet banana crackers.

Salai, salted and sweet banana cackers income were e.i: Rp. 29,566,251.00/year, Rp. 20,286,567.00/year and Rp. 18,437,067.96,/year. Differences in income for salai Rp. was 
larger than Rp. 9,279,684.00/year compared to salted banana crackers and Rp. 11,129,183,/year compared to sweet banana crackers. BEP in unit of salai were 145 packs, 98 for salted banana crackers and 124 sweet banana crackers while BEP in Rupiah for salai Rp. 1,415,636.00 salted banana crackers Rp. 781,352.00 and sweet banana crackers Rp. 988,966.00 with the value of R/C Ratio salai Rp. 1.66, salted banana crackers 1.71 and 1.49 sweet banana crackers.

Because of income, value added, BEP and $\mathrm{R} / \mathrm{C}$, that it higher than another product, salted banana crackers can be recommended as feature product to get market expansion of. Wahyu's home industry.

\section{REFERENCES}

[BPP] Badan Pusat Statistik Kab. Kepahiang. 2016. Kabupaten Kepahiang Dalam Angka 2016. Kab. Kepahiang.

Henry, F. 2009. Investasi (Pengelolaan Keuangan Bisnis dan Pengembangan Ekonomi Masyarakat). Jakarta. Maltra Pritindo.

Imran, S., Murtisari, A., Murni, Ni Ketut. 2014. Analisis Nilai Tambah Keripik Ubi Kayu di UKM Barokah Kabupaten Bone Bolango. Jurnal Perspektif Pembiayaan dan Pembangunan Daerah 1(4): 207 - 212.

Irmayani, D. 2015. Perancangan Program Analisa Break Even Point Dalam Menganalisa Model Investasi. J. Informatika AMIK-LB 3(1): 01 - 21.

Muhammad Nasaruddin, Satria Putra Utama, and Apri Andani. 2015. Nilai Tambah Pengolahan Daging Sapi Menjadi Bakso Pada Usaha Al-Hasanah Di Kelurahan Rimbo Kedui Kecamatan Seluma Selatan. Jurnal AGRISEP. 14(1): 85 - 96.

Ndaliman, M.B., Suleiman, U.Y. 2011. An Economic Model for Break Even Analysis. Conference Paper in Jun 2011, Retrived from https://www.researchgate.net/public ation/256538583

Pratiwi, AN., Tety, E., Yusri, Jumatri. 2015. Analisis Pendapatan Dan Nilai Tambah Agroindustri Tape Singkong Di Kota Pekanbaru. Journal Faperta 2(1): 01 - 11.

Purwitasari, T., Riptanti, W., Sutarto. 2016. Analisis Resiko Dan Nilai Tambah Agroindustri Minyak Kelapa Di Kecamatan Grabag Kabupaten Purworejo. AGRISTA 4(03): 146 - 156.

Rahman, S. 2015. Analisis Nilai Tambah Agroindustri Crackers Jagung. Jurnal Aplikasi Teknologi Pangan 4 (3): 108 111.

Reswita, Kelayakan Usaha Pengolahan Ikan Asin di Kelurahan Sumber Jaya Kecamatan Kampung Melayu Kota Bengkulu. Jurnal AGRISEP 14(2): 247 255

Simin, I. 2014. Analisis Nilai Tambah Buah Pisang Menjadi Keripik Pisang Pada Industri Rumah Tangga Sofie Di Kota Palu. e-J. Agrotekbis 2 (5): 510 - 516.

Soekartawi. 2002. Analisis Usaha Tani. Penerbit Universitas Indonesia (UI-Press), Jakarta.

Soekartawi. 2002. Prinsip Dasar Menejemen Pemasaran Hasil-Hasil Pertanian Teori dan Aplikasinya. Raja Grafindo Persada. Jakarta.

Sudiyono, A. 2001. Pemasaran Produk Pertanian. UMM Press. Malang.

Wiyono, T., Baksh, Rukavina. 2015. Analisis Pendapatan Dan Nilai Tambah Usaha Tahu Pada Industri Rumah Tangga "Wajianto" Di Desa Ogurandu Kecamatan Bolano Lambunu Kabupaten Parigi Moutong. e-J. Agrotekbis 3 (3), 421 - 426.

Zdeñk, K. 2011. Economic Value Added as a Dependence on The Corporate - and Market - Life Cycle. Journal of Competitiveness 2: 71-82. 